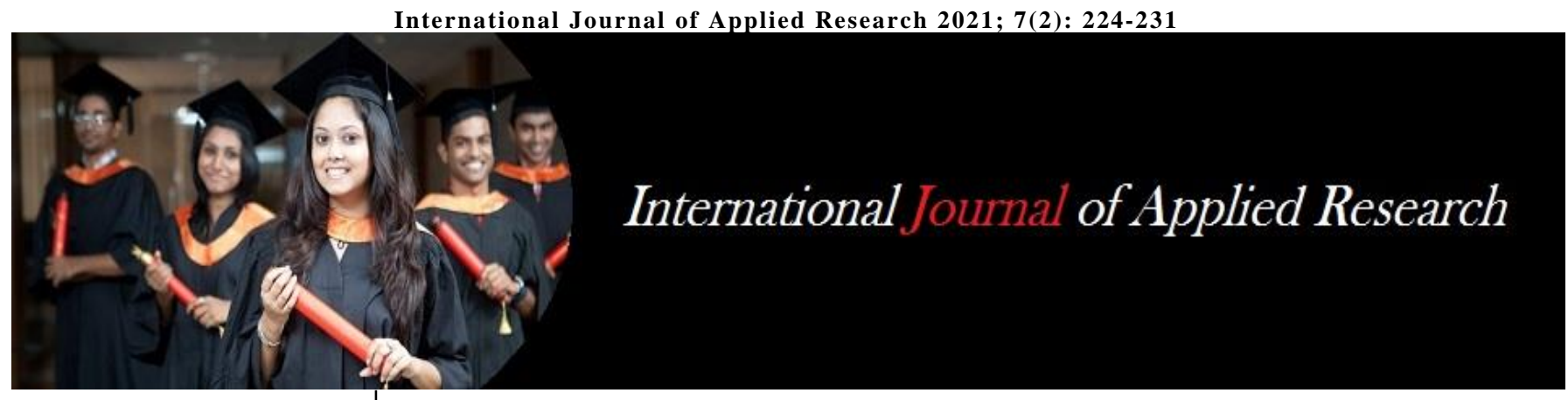

ISSN Print: $2394-7500$

ISSN Online: 2394-5869

Impact Factor: 8.4

IJAR 2021; 7(2): 224-231

www.allresearchjournal.com

Received: 16-12-2020

Accepted: 20-01-2021

Aman Verma

MPhil-PhD, Research Scholar

Center for East Asian Studies

(Korean Division) School of

International Studies

Jawaharlal Nehru University

New Delhi, India
Corresponding Author:

Aman Verma

MPhil-PhD, Research Scholar Center for East Asian Studies (Korean Division) School of International Studies

Jawaharlal Nehru University New Delhi, India

\section{Discourse on nationalism in colonial period of Korea}

\section{Aman Verma}

DOI: https://doi.org/10.22271/allresearch.2021.v7.i2d.8281

\begin{abstract}
Nationalism may be described as a frame of mind in which a person perceives that his fellow members owe his or her supreme loyalty to the nation-state. Resilient attachment to own country, indigenous culture, and the conventional local authority can be present in the long history of a nation, but nationalism in modern sense presumes the existence of a nation and a sheer will to modernize itself to protect the sovereignty of a particular nation.

The colonial period of Korea lasted from August 1910 to August 1945. During the colonial period, the Korean nationalism became strongly anti-colonialism and anti-imperialism. Its ultimate objective was to oust the Japanese imperialist forces from the Korean peninsula, and its immediate task was to preserve the racial and cultural heritage of the Korean people.

The development of nationalist narratives in the subsequent colonial period also resulted in an ideological and political clash among the Korean nationalists. After the March First Movement, the governor-general of Korea allowed some relaxations for cultural activities. The nationalists utilized this opportunity to further develop the nationalist discourses. With the integration of international narratives such as socialism and liberalism, diverse forms of anti-colonial discourses developed in Korea which resulted in "ideological schisms" among the nationalists of Korea during the 1920s. Although, there was a commonality in the objective of ousting the Japanese imperial power from the Korean peninsula. There also developed the contentious relationship between competing groups such as reformists and leftists and rose to its peak in the early 1930s.

In this research paper, I shall argue that that Korean nationalism discourse during the colonial period evolved more as anti-colonial in nature despite political and ideological indifference. Also, I shall look into the different phases of the Japanese rule and the Korean response to analyse the Korean nationalism discourse during the colonial period.
\end{abstract}

Keywords: Korean nationalism, colonial period, Ideological Schism, Cultural movement

\section{Introduction}

The colonial period of Korea lasted from August 1910 to August 1945. During the colonial period, the Korean nationalism became strongly anti-colonialism and anti-imperialism. Itsultimate objective was to oust the Japanese imperialist forces from the Korean peninsula, and its immediate task was to preserve the racial and cultural heritage of the Korean people. Protesting the Japanese annexation of Korea, many nationalists fled from Korea. An Ch'angho a staunch nationalist wrote a song when leaving Korea: "I am forced to leave you, my beloved land...but I shall always think about you wherever I go...Do not forget me my beloved country, as I shall not forget you." The nationalist leaders who remained in Korea went underground and formed secret societies such as the National Associations of the Koreans and the league of National Restoration. The students who were in Korea or went outside joined the nationalist movements of Korea. A new element of "we consciousness" was introduced during this period carrying the racial tincture and nationalist historians promoted the concept of collective ethos during the period. Koreans were also able to resist the Japanization program through cultural nationalism which was unique in nature as we find a very rare example of any colonial power to obliterate the culture and heritage of their colony. The period from the Japanese annexation of the Korean peninsula in 1910 till the March First Movement is referred to as the period of dormancy of the anti-Japanese nationalist movement. This was the period when Korean people inherited the nationalist spirit of independence of the late Choson Dynasty and accumulated the potential that was later unleashed in the form of the March First Movement. It is interesting to note that the year March First Movement broke out, Civil disobedience movement broke out in India and 
later in China. The May Fourth movement emerged in China. Thus, the year 1919 was the turning point for the nationalist movement not only in Korea but also in Asia.

Despite various rules, regulations, and ordinances of the Japanese issued against the Koreans from 1910, the Koreans expressed their nationalism through passive resistance movement. Although we cannot ignore the violent expressions though was made sporadically and the further the Japanese suppressed the violent resistance with double violence. The March First Movement reflects that although there were differences in terms of religious affiliations and political orientations, the nationalists had coordinated well towards the goal of national independence from Japanese colonial yoke.

The development of nationalist narratives in the subsequent colonial period also resulted in an ideological and political clash among the Korean nationalists. After the March First Movement, the governor-general of Korea allowed some relaxations for cultural activities. The nationalists

utilized this opportunity to further develop the nationalist discourses. With the integration of international narratives such as socialism and liberalism, diverse forms of anticolonial discourses developed in Korea which resulted in "ideological schisms" among the nationalists of Korea during the 1920s. Although, there was a commonality in the objective of ousting the Japanese imperial power from the Korean peninsula. There also developed the contentious relationship between competing groups such as reformists and leftists and rose to its peak in the early 1930s.

These competing nationalist forces critiqued each other so heavily that they considered each other as the "enemies of the nation". Indeed the cultural and political process of a country invariably contains various competing narratives as happened in the case of colonial Korea. Also, Tom Nairn's opinion about the Janus-faced nature of nationalism highlights the importance of the past and restoration of a sense of pride in its past historical memory and cultural forms in developing a culturally richer form of nationalism. Thus the leaders of the nationalist movements during the colonial period did no invent nationalism but reinterpreted the popular memories of traditional identities to refashion them as the content of nationalism. It was also the period when Nationalist historians adopted modern epistemology of writing Korean history which was more people centered rather than archaic practice of writing dynastic history.

In this chapter, I shall highlight the Korean nationalist discourse in the colonial period. I shall also try to answer the questions, what were the political conditions that shaped the nationalism discourse during the colonial period? What was the nature of Korean nationalism during the colonial period? In doing so, I shall argue that that Korean nationalism discourse during the colonial period evolved more as anticolonial in nature despite political and ideological indifference. Also, I shall look into the different phases of the Japanese rule and the Korean response to analyse the Korean nationalism discourse during the colonial period.

The March First Movement and the Modern Korean Nationalism

The March First Movement 1919 was the first righteous and non-violent demonstration of the Koreans during the colonial period which was inspired by the concept of "one people, one nation." On March First, 1919, hundreds of Koreans from all walks of life joined in demonstrations to declare Korea's natural right for independence from the
Japanese yolk of colonial rule. It seemed that the Korean nation awoke from decade long sleep. The March First movement was organised brilliantly with pacifist intent, however, that whole Korean summer the demonstration turned into sustained rioting happened throughout Korea. Even the Japanese colonial authority was surprised. Henceforth suddenly colonial population vocally denouncing Japanese rule resulted in swift and brutal Japanese suppression. Although the number of participants is controversial according to Andrew C. Nahm some two million participated in this mass demonstration, which resulted in 7,700 deaths, 45,600 wounded, and 47,000 arrested. (Nahm, Feb 1983, 25) ${ }^{[37]}$.

The March First movement marked an important watershed in the history of modern Korean nationalism. Robinson notes that Korean nationalism "had become a mass phenomenon, no longer the monopoly of the Westernized intellectual elites." It is true in the sense that various factors such as the spread of communication and literacy and most importantly a decade of harsh rule of the Japanese together instilled the consciousness of nationalism among the Korean mass. The success of the aroused national consciousness was based on Korea's right to self- determination ${ }^{1}$ in the existing Westphalian world order.

Even though all the signatories of the declaration were arrested and could not provide leadership to the masses. But here one thing is important that the mass support which lacked during the nationalist reform movement before 1910 was now available to drive the nationalist force for independence.

The popular slogan of the March First Movement was the Tongnip Manse (Long Live the Independence), an expression of fervent aspiration and advocacy of 'complete independence.' Since the inception of modern Korean nationalism in the late-Choson dynasty, the theory of complete independence was a wide-spread concept. However, after the Japanese colonisation of Korea, the theory of complete independence was further reinforced and envisioned a completely independent nation-state. The movement also proclaimed the establishment of democraticrepublican polity after complete independence as it is evident in the Declaration of Independence. ${ }^{2}$

The movement failed in its primary objective of political independence from Japanese rule. However, the movement manifested the anti-Japanese sentiments among the Koreans. Also, the movement led the Japanese to realize that coercion alone could not secure the stability of colonial rule. (Kang, 2011, 59). The movement reflected the resilient resistance against the Japanese repressive control. Indeed, diverse groups of Koreans ranging from peasants, landlords, intellectuals, students, and religious affiliates gathered around the demand for political independence. The March First Movement also demonstrates the contentious relationship between the Japanese authority and the Korean mass, a prevailing form of conflict throughout the first decade of colonial rule.

1 Dae-yeol Ku, Korea under Colonialism: The March First Movement and Anglo-Japanese Relations (Seoul: Royal Asiatic Society, Korea branch, 1985), p.p. 37-45. Op cit.

${ }^{2}$ The idea to establish republicanism was first put forward in 1898 by the leaders of People's Assembly. The

New People's Association in 1907 proclaimed that after restoring the national sovereignty republican

government will be established 


\section{Korean Nationalism from the 1920s -1930 s.}

Indeed, the March first movement instilled a fear in the Japanese colonial authority. This resulted in significant policy changes in colonial Korea after 1919. The Japanese government under Hara Takashi was forced to change the policy towards colonial Korea. Seeing the impact of the March First Movement and realising that military repression would arouse the nationalist sentiments, the Japanese government was forced to change its military policy of Terauchi and Hasegawa to the appeasement policy of Saito Minoru. The new appeasement policy is known as imperial cultural policy (Bunka Seiji).

\section{Developing Ideological Schism in the early 1920s}

As the new regime exhibited the political leniency and gave space for free speech and assembly of the people, there also arose the intense debate between the nationalists on how to restructure the nationalist discourse. Many Korean intellectuals had aspired to Western liberalism as their political ideal. However, the west had failed to aspire to these Korean ideals and failed to show any intention of practising Wilson's Fourteen Points. Disillusionment with Western liberalism forced the Korean intellectuals to reexamine their past and contemplate the future of Korea. (Lee, 1963, 238) ${ }^{[29]}$. This resulted in the ideological schisms as one faction devoted their energy to purely the nationalistic theme of "strength for Korea" and another faction was attracted more with the ideology of Marxism.

The issue of economic inequality became one of the significant bone of contention between the reformist and the leftists during this period. The colonial state had worsened the economic conditions of peasants in Korea. Although there was general agreement among the nationalist groups given the importance of rural economy the groups had different approaches to resolve the newly emerged economic inequality in Korea. While the socialist nationalists paid more attention to the labour and peasant movements, the reformists focussed on national cooperation. Nationalist reformists saw the owner class as the leader of agricultural development. Tenant disputes were seen as an impediment to economic growth. To solve the tenant disputes, they argued should be prevented in advance through cooperation and coordination between a landowner and the tenant. Kaebyok (Creation) ${ }^{3}$, a leading nationalist magazine at the time had the following view on the tenant problems:-

"The insecure condition of agricultural livelihood affected not merely tenants whose rights to live became violated but also landlords and independent farmers. When people discuss agricultural problems these days, they neglect fundamental issues and only focus on the problem of distribution. The development of agricultural technology and peasants' self- consciousness became possible due to the effort of the land-owner class... Without the landlord class, agricultural development is not even conceivable and independent farmers or tenants will be drawn into a more miserable condition." (Kaebyok, April 1922, 101)

On the contrary, socialist nationalists considered peasant movements as a tool for pressurizing the colonial state for the just demands of tenants who comprised a majority of the

3 Kaebyok was the brainchild of the religious movement Chondogyo. It was one of the longest lived journals of the decade lasting for seventy-two issues (1920-1926) population of colonial Korea. The traditional paternalistic relationship between landlords and peasants was supported by the moderate nationalists while in the eyes of socialists landlords were "unforgivable moral offenders against peasants." (Kaebyok, March 1923, 64). The socialists further argued that the relationship between landowners and tenants was based on power, not on human equality or morality. So they supported the peasant movement as it strengthened the tenant rights of peasants and mobilised the peasants towards solidarity of the exploited class.

On the other hand, moderate nationalists started the Korean production Movement to address the concerns of the economic situation in colonial Korea. The main objective of the movement was to support the Korean industrial production and economic self-reliance for the Koreans. Korean nationalists were also influenced by the Indian Nationalist movement led by Mahatma Gandhi. Cho Mansik (1882-?) formed the society for the Promotion of Native Production (Choson mulsan chnagnyohoe) in July $1920 .^{4}$ Similarly, Yom Tae-jin and Yi Kwangsu formed a group Self Production Association (Chajakhoe) in Seoul in December 1922. The main purpose of these organisations was to encourage the consumption of the native goods for economic prosperity among the Koreans and to bolster the solidarity. They intended to raise national consciousness by rejecting imported goods in favour of products made by Koreans for Koreans. (Robinson, 1968, 95).

The radicals and leftist nationalists denounced moderate leadership tactics as illusionary as the nature of Japanese political authority was underpinned on capitalism and imperialism. For them the real problem was the exploitative class system in which the gradualists were willingly participating (Buzo, 2007, 29) [5]. In their views, the movement was promoting only the economic interest of the Korean bourgeoisie, while peasant and working-class were not being alleviated from the economic burden who comprised the core of the nation.

Another bone of contention in the early 1920s among the Korean nationalists was the issue of relationship with the Japanese colonial state. National reformists proposed the idea of political autonomy within the existing colonial system. After the failure of the March First Movement, nationalist reformists considered that it was almost impossible to achieve immediate independence from the colonial rule and thus Koreans should face the political reality of the country. Seeing the repressive action of the Japanese colonial state, it was more appropriate to strive for self-rule and of a suffrage movement.

Korean nationalists faced challenges to find practical strategy within colonial system as one side they had to resist Japanese colonial rule to obtain political hegemony and at the same time, they had to avoid the charges of being collaborators among the Koreans. Under these circumstances, the nationalist reformists whose approach was gradualist for national independence and prioritize development of self-reliance and strength for the nation over immediate national independence faced harsh critique by leftists and non-cooperating groups as unacceptable tactics

\footnotetext{
${ }^{4}$ During a visit to Japan, Cho was exposed to the idea of Gandhi's non-violence and economic self-sufficiency

for independence from the British rule. Robinson (1988) notes that later because of his commitment to the Gandhi's ideals he earned the label "Gandhi of Korea."
} 
because it assumed the maintenance of the colonial status quo.

In the early 1920s, various nationalist groups propagated varied forms of anti-colonial nationalist narratives. The nationalists sought to devise practical strategies to solve the issues of economic inequality and relationship with the Japanese colonial state. During the process, they co-opted international ideologies such as Socialism and liberalism as the former emphasized Justice and later stressed freedom in colonial Korea. (Kaebyok, September 1921, 36, cited in Kang, 2011, 157). The influence of these international ideologies on different nationalist groups explain the ideological schism. The colonial state strategy of divide and rule also played a crucial role in ideological differences among the Korean nationalist groups.

United Nationalism: 1927-1931

The changing political circumstances in the mid-1920s led both "non-conciliatory nationalists" and the leftists to seek political cooperation. The increased surveillance and repression posed grave threats to the communists. Also, repressive law such as The Maintenance of Public-Acts Order was passed to control the Japanese communists. The same law was implemented in Korea upon the formation of the Korean Communist Party in 1925. The main objective of the law was to tighten control over those who "organised or joined an association to overthrow the existing political system or to oppose the private property system"5 (Kang, 2011, 158).

Inception of communism had created an ideological schism among the Korean intellectuals. (Robinson, 1988. Also see, Gi-wook, 2006) ${ }^{[42]}$. However, many Korean nationalists and socialist observed similarities in the objective of the nationalist and socialist movement and saw the opportunity to collaborate. Han Yong-un, a famous nationalist Buddhist monk, advocated to merge the two movements as they face same issues and problem. He further argued that since Korea lost its national sovereignty a complete social revolution could be achieved only after establishing independent nation-state. Han held that the question whether Korea be a capitalist or socialist country should be dealt only after complete Korean political independence.

Korean socialists had to adopt new politics i.e. adopting the strategy broadening coalition of progressive multi-class forces. Although, reformist nationalists and gradualists leaned more towards home rule and did not show any interest. (Lee, 1963, 251) ${ }^{[29]}$. But more "radical nonconciliatory nationalists" saw the feasibility of uniting in an anti-Japanese movement. As a result, Shinganhoe (New Korea Society) on 15 February 1927 emerged as a national organisation.

The activities of the organisation progressed rapidly. The leadership of the organisation included prominent persons of religious groups (Christianity, Buddhism, and Chondogyo (the Heavenly Way), education, law, and press. So the organisation had no difficulty in mustering strength. Also, the leftist organisations that emerged in the early 1920s at the local level provided significant cadre for the Singanhoe. Within four years of its evolution, Shinganhoe (New Korea Society) had 39, 410 active members and 237 local branches

\footnotetext{
5 The Maintenance of Public-Acts Order was revised in 1928 making it more draconian. Formerly, a person was sentenced from imprisonment for up to ten years for resisting the political system but after revision it was extended up to life imprisonment or death penalty. (Kim 1995: 137)
}

located at the county level in all provinces in Korea (Choson Ilbo, May 18, 1931, cited in Kang, 2011, 160).

The Shinganhoe (New Korea Society) played a crucial role in coordinating and integrating various social and political activities and organisations including labour/tenants unions and women's organisations at the local and national levels. Women were mobilized in the Sharon Friend Society (Kunu-hoe) (Lee, 1963, 253) ${ }^{[29]}$. Shinganhoe (New Korea Society) also coordinated with the youth organisation All Korean Youth federation (Choson chongnyon chongdonmaeng) (Kang, 2011, 161).

Shinganhoe (New Korea Society) served to enhance the national consciousness and acted as "indirect opposition" to the Japanese colonial administration. For example, In the Kwangju student incident of 1929, Shinganhoe (New Korea Society) worked in the background to instigate the students to develop it further into a more general anti-colonial struggle.

At least there were three main factions active in Singanhoe (New Korea Society) - The leftists, the moderates, and the non-communist radicals. These factions advocated different tactics and professed different ideologies apart from their common struggle against the Japanese colonial occupation.

Conclusively, the formation of Shinganhoe (New Korea Society) provided an opportunity to the nationalist groups emerged in the 1920s to develop a cooperative relationship and to channelize the anti-Japanese sentiments of the Korean masses in unison. However, the political competition among different nationalist groups to acquire hegemonic positions within the organisation and intense political control of the colonial government served as a conduit for increasing ideological conflict which resulted in the dissolution of Shinganhoe (New Korea Society).

\section{Cultural nationalism, the 1920s -1930s.}

A Japanese government official complained that "immediately after the Manse disturbance (March First Movement of 1919), every corner of Korea was filled with anti-Japanese feelings." The Japanese government in Japan appointed a civilian as a governor in colonial Korea fearing that more military repression rule could further instigate nation-wide protests like the March First movement of 1919. The new civilian governor initiated a new cultural rule known as Bunka Seiji, which allowed some limited space for cultural activities. As a result, limited cultural activities resumed in the 1920s. It is also to note that cultural policy was designed to incorporate the moderate nationalists into the colonial system. As far as the cultural activities did not challenge the colonial rule directly, Koreans were allowed to publish the newspaper and magazines. During the 1920s to 1930 s, colonial saw the growth of "print capitalism."

According to Anderson's thesis (1983), Print capitalism played crucial role in the birth of western nationalism, similarly, Korean nationalism further developed with the growth of "print capitalism" during this period.

Korean nationalists especially moderates believed that national consciousness can be raised by focussing on cultural areas rather than opposing directly to the colonial ${ }^{6}$. They initiated various movements such as the university movement, the Korean production movement, Korean

\footnotetext{
6 As we have seen above, the radical and non-conciliatory nationalists, some influenced by communism proposed more direct political challenge for independence to the colonial authority
} 
language movement to promote national spirit and identity among Koreans. They sought to reconstruct the Korean national identity based on modern western liberal thought. Yi Kwangsu one of the pioneers of cultural nationalism offered a roadmap of the Korean nationalist movement. He stressed that a concrete step towards national reconstruction was to lead a national movement based on moral and spiritual values than political as nurturing Korean nationality was more important than political independence (Shin Gi-wook, 2006, 46-47) ${ }^{[46]}$.

$\mathrm{Yi}$ considered 'reconstruction of the nation involved reforming the nation's inner character as well as its outer

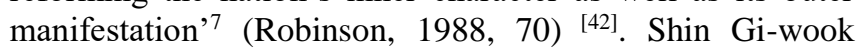
(2006) ${ }^{[46]}$ notes that after an increased Japanese assimilation program, cultural nationalists started increasingly defined nation in racial and collectivistic terms. They searched for unique national symbols in Korea's folk tradition. They tried to inculcate the indigenous symbols and western ideas to create a national identity.

However, Yi Kwangsu's views shifted radically from his early views emphasizing cultural nationalism to ethnic nationalism especially in the 1930s as Japanese assimilation attempt intensified under the slogan naisen ittai (Korea and Japan as a single body). As Shin Gi-wook (2006) ${ }^{[46]}$ notes that $\mathrm{Yi}$ in his earlier work "Minjok Kaejoron" (Treatise on the Reconstruction of the Nation) focussed on the construction of new Korean nationality to create a new Korean nation but a decade later in his work "Choson minjongnon" (A Theory of the Korea Nation) he presented a highly racialized view of the nation. He defined a nation in terms of Hylotong (blood-line), Songgyok (personality), and Munhwa (culture) (Shin Gi-wook, 2006, 48) ${ }^{[46]}$ shifting from his former view on nationality terms. Thus, we find that cultural nationalism that started during the 1920s shifted dramatically in the 1930s carrying the tones of ethnicity. This shift can be viewed in the rise of colonial racism and international socialism. (Shin Gi-wook, 2006, 48-49) ${ }^{8}$.

\section{The culmination of the Cultural Nationalist Movement}

The cultural movement continued throughout the 1920s and early 1930s. Despite its initial success, the movement was dismantled in the 1930s as it failed to sustain its promise as a solution to long term problems of Korean independence. Robinson (1988) ${ }^{[42]}$ argues that Cultural nationalism was a response from the expanding radical nationalists within colonial Korea. The Socialist and Marxist writers heavily critiqued the fundamental precepts of the cultural nationalism. They argue that without political freedom it was baseless to have the national development, thus questioning the utility of national reform within the colonial system. Further, they questioned the cultural nationalist leadership's advocacy of economic and cultural development. They believed that such kind of movements only serves the interest of only middle and upper-class

\footnotetext{
7 Similarly, Korean socialists who were trying to lead Korean nationalist movement based on economic equality

tried to propound the socialist consciousness at the cost of Korea's cultural and historical heritage

${ }^{8}$ Shin Gi-wook states that "Robinson explains the rise of Marxism in the mid-1920s as Korean radicals' response to non-political cultural nationalism. Similarly, Shin Gi-wook argues that rise of "ethnic nationalism" in the late 1920s and early 1930s was Korean nationalists' response to international socialism. (For detailed information, see, Shin Gi-wook (2016) 58-78)
}

Korean elite. Also, division among the leadership over the issues class versus national interests and tactics for anticolonial movement further undermined and diluted the mass appeal of the cultural movement.

The emergence of pro-Japanese organisations which emulated political and social reforms of the cultural nationalists further diluted the impact of the cultural nationalist program by blurring the line between gradualist movement devoted to future political independence and collaborative pro-Japanese organisations.

$Y i$ Kawangsu, one of the leading figures of the cultural nationalist movement was arrested in 1937. His article, "Minjok Kaejoron" (Treatise on the Reconstruction of the Nation) initially was able to make a deep imprint among the intellectual circles of colonial Korea. His nationalist discourse appealed to the Korean reformist nationalists to rediscover the history, language, and religion of Korea to reshape the Korean national identity based on western values and ethics. However, after his arrest, we see a paradigm shift in his political stance and arguably he became a pro-Japanese, betraying his prior beliefs which further undermined the cultural nationalism.

By the late 1930s, many cultural nationalists were arrested as the Japanese colonial government once again had become oppressive due to its Manchurian military expedition. The Japanese government also ended its cultural policy by 1932 . Due to these political and military circumstances, the cultural nationalism had to suffer as it relied more on the Japanese government's cultural policy.

In the end, the cultural nationalist movement failed to deepen its roots in Korean society and achieve mass support because it did not serve the interests of the majority of Koreans. Although the idea of independent Korea was entrenched in the minds of Korean masses by the early 1920s how to translate into political action was still a prevalent question. The cultural nationalist movement failed to change the political reality of the Korean peninsula.

\section{Korean Nationalism from the 1930s to 1945.}

The 1920s was the era of appeasement than outright repressions for the Koreans. Although, there were suppressions of the dissent we cannot deny the fact that there was some degree of tolerance. However, the situation of limited tolerant Japanese rule in Korea began to change after 1931 with the military rise in mainland Japanese politics. The Japanese colonial authority put immense pressure on the Korean nationalist leaders to support the Japanese cause outside the Korean peninsula ${ }^{9}$ and noncooperation was regarded as a hostile action.

The policy of Japanization has always been on the agenda since the Korean annexation in 1910. However, till now the Japanese colonial authority were not able to implement their agenda rigorously. The Sino-Japanese war provided context for the intensification of the assimilation program. As we know that war requires a huge mobilisation of resources and manpower. In this case, Korea was an ideal colonial state for the Japanese to serve the purpose of Japanese interests in China due to the Korean strategic location between Japan and China. Also, as the war expanded, the casualties

\footnotetext{
${ }^{9}$ After World War I, Japan gained hegemonic position in the Far East Asia. The Japanese were more involved in the conflict with China and Manchuria and saw Korea as increasingly strategically valuable for its military operations in China and Manchuria and South East Asia
} 
mounted and the Japanese desperately needed Koreans as a reserve for the Japanese military. These factors played a major role in augmenting the speed of the assimilation program.

The Japanese chose to accelerate the assimilation program. In 1938, the government abolished Korean language instruction in all secondary schools. It was also followed in elementary schools and later the use of the Japanese language became mandatory in schools in Korea. Teachers in Korean schools started their instruction with veneration to "the Sun in the East" and worship of the Shinto shelf placed on the shelf in the classroom (Lee, 1963, 265) ${ }^{[29]}$. Students were taught about "the superiority of the Japanese race" of which the Korean people were to be the part. Interestingly, these rituals were not confined to the schools but also the government agencies, factories, and any kind of public gatherings. Mobilisation to the Shinto shrines became a must to every member within Korea irrespective of their economic, social, and religious background at least once a month.

Korean people were also encouraged to change their monosyllabic surnames to the multisyllabic Japanese forms. Lee (1963) ${ }^{[29]}$ notes that Koreans were free to choose any Japanese names as long as they were not distinctly Korean names. Colonial police and authorities were mobilized to implement these cultural co-optation programs and those who opposed had to face food-ration cut off and their children were barred from the schools if families did not comply within the stipulated time (Lee, 1963, 265) ${ }^{[29]}$.

The nationalist leaders showed varied reactions to the ongoing cultural obliteration in Korea. Although some chose or were persuaded to collaborate with the regime. Some of them were genuinely impressed by the Japanese style of modernisation and wished Korean people to take the opportunity for their self-growth while there were also who was cooperating because of police pressure. A police report in 1938 stated that half of the formerly nationalist and socialistic organisations still existing at that time - youth, labour, farmer, etc., - either collaborated with or paid lip service to the Japanese assimilation policy (Lee, 1963, 266) [29].

Although the communists had the vision of communizing Korea, they always advocated freedom from the colonial yoke. The combination of nationalism and communism had a potent appeal and was much successful in attracting youths and intellectuals from every corner of the Korean peninsula. Many young Koreans joined communist nationalist groups when they were convinced that the moderate nationalist movement could not accomplish the goal of national freedom from Japanese colonialism and only class warfare on a mass scale would bring emancipation of the country.

The last phase of the Japanese rule also the second "dark age" for the Koreans under the Japanese colonial rule saw the active collaboration of the nationalists and ideological conversion of the majority of the leftists which led to the significant decrease in the political activities in colonial Korea. Nationalist reformists rendered their support more directly to the Japanese colonial policy and communists' activities were largely restrained by the sudden ideological conversion, Government-General, and factional conflicts. Thus, overall nationalist movement activities became relatively dormant during this period.
Thus, in the last phase of the Japanese rule, colonial Korea saw the political split between nationalist reformists and leftist activists. Due to the significant influence of ideology, they developed opposing nationalist frames and pursued widespread mobilization for nationalist goals and adopted different approaches. Although, there were differences in terms of elitist and popular approaches or in terms of topdown and bottom-up mobilization the major bone of contention between them was how to rearticulate the nationals living under colonial rule and how to redefine the nation under new colonial environment. They selectively defined the notion of "nation" and "people" fitting into their ideological frameworks. Thus, nationalist reformists and communists developed their interactions with the colonial government. Based on these facts, they rearticulated and redefined the boundary of inclusion and exclusion of the nation becoming enemies of the nation of each other.

\section{Conclusion}

The annexation of the Korean peninsula by the Japanese in 1910 added a new chapter in Korean nationalism. The development of nationalist discourses in colonial Korea discloses the coexistence of multiple strands of nationalist discourses. Colonialism had a paradoxical effect upon Korean nationalism. Although, nationalists were divided into different groups such as leftists, non-compromising nationalists, nationalist reformists but at least during the early colonial period they shared the same objective of getting political independence from Japanese colonialism. They co-opted popular international ideologies such as liberalism and socialism in Korean nationalism discourse.

Thus we can say that evolution of Korean nationalism in the colonial period reflects the role of interaction of international ideologies and native events in articulating the nationalist discourses in colonial Korea. Korean nationalism during the colonial period can also be seen in the context of response to the changing socio-economic and political conditions in colonial Korea.

Despite Korea having ethnic homogeneity and anti-Japanese sentiments, there existed competing nationalist discourses that varied in strategies for different nationalist groups. Although the nationalist reformists and leftists came together to form Shinganhoe (The Advancement Society) which resulted in the "united nationalism" against Japanese colonialism during the later phase of the Japanese colonialism, Korea nationalism was not merely the dichotomy relationship between the colonial state and Korean nation as suppressant and resistant.

While articulating the anti-colonial discourses, Korean nationalists and leftists also demanded colonial authority to promote industrial development of the colony and protecting the economic welfare of the peasants and workers. While non-compromising nationalists were unable to develop their political strategy to deal with the colonial regime. They lacked an organisational base thus their movement had a limited impact on the general population and finally explain their political inactivity in the later phase of the Japanese rule. Due to different strategies, nationalist reformists and leftists had the contrasting view which led to the political and ideological polarisation in the 1930s.

As the leftists and nationalist reformists relied on socialism and liberalism respectively for propagating their political views against Japanese imperialism and colonialism, the inherent contrast between these international ideologies led 
to the shaping of the initial clash between Korean nationalist groups. Here, it important to note that although international ideologies had an impact on the nationalist discourses it did not only determine the form and content of the nationalist narrative framework in colonial Korea. The international ideologies itself were selectively used to fit in the Korean context by the nationalist reformists and leftists.

Liberalism and socialism were used by the nationalists as a tool to interact with the colonial regime. The colonial government supported and cooperated nationalist reformists to have a close eye and to maintain the political orientation of the colonial system, on the other hand, it held tight control on the leftists and radical nationalists due to their non-compromising attitude, mobilisation of radical social and economic movements, and opposition directly to the colonial rule.

Leftists inherently used "class" or "people" over "nation" to accomplish the national emancipation from the colonial yoke. They emphasized the "revolution from below." That is why they mobilized peasants and industrial workers by raising economic and social issues. They led the radical social movements through peasants and labour unions which directly opposed the Japanese colonial rule. Although leftists placed "people" over the "nation" they never abandoned the question of national liberation throughout the colonial rule. As a critical result, leftists and noncompromising nationalists became alienated with reformists and moderates who remained apolitical and even cooperated or collaborated with the colonial state. Thus, the strategic approach and "divide and rule" policy of the colonial state played a seminal role in growing differences between reformists and leftists.

Even though the political activities of both nationalist reformist and leftists were prohibited in the late colonial period but the imagination of the Korean nation-state that continued through the dynamic relationship between the colonial state and the nationalist groups became the inherent source of internal conflict after liberation from the Japanese rule and during U.S. and Soviet Union occupation period.

\section{References}

1. Allen, Chizuko "Northeast Asia Centered Around Korea: Ch'oe Namson's View of History", Journal of Asian Studies 1990;49(4):787-806.

2. Anderson, Benedict. Imagined Communities: Reflections on the Origin and Spread of Nationalism, London: Verso 2006.

3. Anderson, Emily. Belief and Practice in Imperial Japan and Colonial Korea, Auckland: Palgrave Macmillan 2017 ,

4. Baldwin Jr, Frank P. The March First Movement: Korean Challenge and Japanese Response, Ph.D. Thesis, Columbia: Columbia University 1969.

5. Buzo, Adrian. The Making of Modern Korea, New York: Routledge 2007.

6. Caprio, Mark E. Japanese Assimilation Policy in Colonial Korea, 1910-1945, Seattle: University of Washington Press 2009.

7. Cha, Ki-Pyok. "Political Thought behind Korean Nationalism", Korea Journal 1976;16(4):4-20.

8. Ch'a, Ki-byok. "Trials and Challenges Facing Korean Nationalism", Korea Journal 1966;6(12):31-43.
9. Chandra, Vipan. "An Outline Study of the Ilchin-hoe (Advancement Society) of Korea”, Occasional Papers on Korea 1974;(2):43-72.

10. Chandra, Vipan. "Sentiment and Ideology in the Nationalism of the Independence Club (1896-1898)", Korean Studies 1986;(10):13-34.

11. Chandra, Vipan. "Imperialism, Resistance, and Reform in Late Nineteenth-Century Korea: Enlightenment and the Independence Club", Berkeley: Center for Korean Studies, University of California 1988

12. Chandra, Vipan. "The Concept of Popular Sovereignty: The Case of So Chae-p'il and Yun Ch'i-ho", Korea Journal 1981;21(4):4-13.

13. Chatterjee, Partha. Nationalist Thought and the Colonial World: A Derivative Discourse, London: Zed. 1986,

14. Chong, Ray Key. "The Tonghak Rebellion: Harbinger of Korean Nationalism", Journal of Korean Studies, 1969;1(1):73-88.

15. Cummings, Bruce. Korea's Place under Sun: A Modern History of Korea, New York: WW. Norton \& Company. 1997,

16. Duara, Prasenjit. Rescuing History from the Nation: Questioning Narratives of Modern China, Chicago: University of Chicago Press 1995.

17. Duncan, John B. "Proto-nationalism in Premodern Korea”, in Sang-Oak Lee and Duk- Soo Park (eds.) Perspectives on Korea, Sydney: Wild Peony 1998.

18. Em H Henry. "Nationalism, Post-Nationalism, and Shin Ch'ae-ho", Korea Journal 1999;39(2):283-317.

19. Gellner, Ernest. Nations and Nationalism. Ithaca, N.Y.: Cornell University Press. Hong, I-sop (1966), "Historical Characteristics of Korean Nationalism", Korea Journal 1983;6(12):14-17.

20. Hwang, Kyung Moon. "New Conceptualizations of Kukka ("state") in Korea, 1896-1910", paper presented at annual meeting of the Association of Asian Studies, Boston 1999.

21. Hwang, Kyung Moon. "Country or State? Reconceptualising "Kukka" in the Korean Enlightenment Period: 1896-1910", Korean Studies, 2000;24:1-24.

22. Janelli, Roger, Dawnhee Yim. Ancestor Worship and Korean Society, Stanford, CA: Stanford University Press 1982.

23. Janelli, Roger. "The Origin of Korean Folklore Scholarship", Journal of American Folklore, 1986;(99):24-49.

24. Kang, Hildi. Under Black Umbrella: Voices from Colonial Korea, 1910-1945, Ithaca, NY: Cornwell University Press 2001.

25. Kim KW. "Ideology and Political Development in South Korea”, Pacific Affairs 1965;38(2):164-76.

26. Kim, Key-huik. The last phase of the East Asian World Order: Korea, Japan and the Chinese Empire, 18601882, Berkley and Los Angeles: University of California Press 1980.

27. Kim, Janice. To Live to Work: Factory Women in Colonial Korea, 1910-1945, Stanford, CA: Stanford University Press 2008.

28. Kim, Joong-seop. The Korean Paekjong under Japanese Rule, London: Routledge Curzon 2006. 
29. Lee, Chong-sik. The Politics of Korean Nationalism, Los Angeles and Berkley: University of California Press 1963.

30. Lee, Chong-sik. Japan and Korea: The Political Dimension Stanford, Calif.: Hoover Institution Press 1985.

31. Lee, Hong Yung, Ha Yong-Chool, Sorenson Clark W. (eds.), Colonial Rule and Social Change, 1910-1945, Seattle: University of Washington Press 2013.

32. Lee, Yong-hee. "Problems of Korean Nationalism", Korea Journal 1966;6(12):4-30.

33. Lee, Kwang-rin. Korean Responses to Social Darwinism”, Korea Journal 1978;(18):65-70.

34. Lee, Kwang-rin. "The Rise of Nationalism in Korea", Korean Studies 1986;(10):1-12.

35. Leifer, Michael. (ed.) Asian nationalism, London: Routledge 2000.

36. Mishra, Kumar Sandip. "Korean National Identity Discourse: Evolution, Colonialism, and Division", The Journal of Northeast Asian History 2011;8(2):5-33.

37. Nahm C. Andrew "Korean Nationalism: Its Origins and Transformation”, Korea Journal 1983;23(2):19-37.

38. Palais, James B. Politics and Policy in Traditional Korea, Seattle: University Washington Press 1991.

39. Palais James B. Confucian Statecraft \& Korean Institutions: Yu Hyongwon and the Late-Choson Dynasty, Seattle: University of Washington Press 1996.

40. Robinson E Michael. "Ch'oe-Hyon-bae and Korean Nationalism: Language, Culture, and National Development", Occasional Papers on Korea 1975;(3):19-33.

41. Robinson, Michael. "National Identity and the Thought of Sin Ch'aeho: Sadaejuui and Chuch'e in History and Politics," Journal of Korean Studies 1984;(5):121-42.

42. Robinson Edson Michael Cultural Nationalism in Colonial Korea, 1920-1925, Seattle: University of Washington Press 1988.

43. Robinson F Michael, Robinson E Michael. "Nationalism and the Korean Tradition, 1896-1920: Iconoclasm, Reform, and National Identity", Korean Studies 1986;(10):35-53.

44. Schmid, Andre. Korea between Empires, 1895-1919, New York: Columbia University Press 2002,

45. Shin, Gi-Wook, Michael Robinson. eds. Colonial Modernity in Korea. Cambridge, Mass.: Harvard University Press 1999.

46. Shin, Gi-wook. Ethnic Nationalism in Korea: Genealogy, Politics, and Legacy, Stanford, Calif.: Stanford University Press 2006.

47. Shin, Yong-ha. Modern Korean Nationalism, Translated by N. M. Pankaj, (Korean Studies), Seoul, Korea: Jimoondang Publishing Company 2000.

48. Tikhonov, Vladimir. Social Darwinism and Nationalism in Korea: the Beginnings (1880s-1910s) "Survival" as an Ideology of Korean Modernity, Leiden. Boston: Brill 2010 ,

49. Tikhonov, Vladimir (Pak Noja) "Korean Nationalism" Seen through the Comintern Prism, 1920s-30s. Region, 2017;6(2):201-224.

50. Wells M Kenneth. "Yun Ch'i-ho and the Quest for National Integrity: The Formation of a Christian Approach to Korean Nationalism at the End of the Choson Dynasty", Korea Journal 1982;22(1):42-59.
51. Wells M Kenneth. (ed.) South Korea's Minjung Movement, Honolulu: University of Hawai'i Press 1995.

52. Wells M Kenneth Korean Independence Movements under Japanese Colonial Rule 1910-1937: A Study of Nationalism, M.A. Thesis, Christchurch: University of Canterbury 1979. 